\title{
Effect of the addition of inulin on the nutritional, physical and sensory parameters of bread
}

\author{
Jacira Antonia Brasil, Karina Correia da Silveira, Silvana Magalhães Salgado*, \\ Alda Verônica Souza Livera, Zelyta Pinheiro de Faro, Nonete Barbosa Guerra
}

\author{
Laboratory for Testing and Analysis of Food, Nutrition Department, Center for Health Sciences, \\ University Federal of Pernambuco
}

\begin{abstract}
The present work evaluated the effect of the addition of inulin on sensory, nutritional and physical parameters of white bread. Three formulations containing $0 \%, 6 \%$ and $10 \%$ of inulin were produced. Physical analyses of mass, volume, specific volume, density, centesimal composition, glycemic index (GI) and qualitative descriptive sensory analyses, were carried out. The reduction in bread volume seen with $10 \%$ inulin was higher than that reported in the literature. Bread weight did not differ statistically. There was an $85 \%$ reduction in fat content for bread with $6 \%$ inulin and $86 \%$ for bread containing $10 \%$ inulin. Glycemic index in bread containing 10\% inulin was lower than bread with $6 \%$ inulin and equal to inulin-free bread. A level of $6 \%$ inulin added to bread was regarded to yield good sensory quality.
\end{abstract}

Uniterms: Inulin/effect of application. White bread/analysis. Fat/substitutes. Foods/ sensory analyse.

\begin{abstract}
O presente trabalho avaliou o efeito da adição de inulina sobre os parâmetros sensoriais, nutricionais e físicos do pão branco. Foram desenvolvidas três formulações contendo $0 \%, 6 \%$ e $10 \%$ de inulina. Foram realizadas análises físicas de massa, volume, volume específico, densidade, composição centesimal, índice glicêmico (IG) e análise sensorial descritiva quantitativa. A redução do volume do pão contendo 10\% de inulina foi maior que os dados da literatura. O peso do pão não diferiu estatisticamente. Houve uma redução de $85 \%$ do teor de gordura do pão com $6 \%$ de inulina e $86 \%$ para o pão com $10 \%$ de inulina. O índice glicêmico obtido no pão com $10 \%$ de inulina foi menor do que o com $6 \%$ de inulina e igual ao sem inulina. O pão adicionado de $6 \%$ de inulina foi tido como de boa qualidade sensorial.
\end{abstract}

Unitermos: Inulina/efeitos da adição. Pão branco/análise. Gordura/substitutos. Alimentos/análise sensorial.

\section{INTRODUCTION}

With the aim of reducing the risk of non-transmissible chronic illnesses, many bioactive constituents found in victuals are being extracted for use in a range of formulations. As an example, we can highlight the carbohydrate inulin found mainly in endive roots (Cichorium intybus $\mathrm{L}$ ) and in other species of vegetables that grow in temperate regions.

Inulin presents a hygroscopic property and is able to reduce the available water contents during gelatinization of starch, causing carbohydrates to be less absorbed,

*Correspondence: S. M. Salgado. Laboratório de Experimentação e Análise de Alimentos, Departamento de Nutrição, Universidade Federal de Pernambuco. Av. Prof.Moraes Rego, s/n, Cidade Universitária, 50670-00 - Recife - PE, Brasil. E-mail: silvanasalgado@ufpe.br leading to a lower glycemia rate (Capito, Filisetti, 1999; Saad, 2006). Besides the physiologic effect on glycemia outlined, the addition of these fructans is promising as they do not alter the appearance or flavor of foods. Moreover, the substance adds softness and moistness allowing its use as a substitute for fat in starch-rich products such as cakes, biscuits as well as pasta for soup and spaghetti (Franck, 2002).

Studies carried out have determined that the addition of $5.7 \%$ of inulin to white bread as a substitute for fat, did not affect its sensory characteristics (Lajolo, Menezes, 2006). Wang et al. (2002), while studying the quality of bread enriched with inulin, algarroba fiber and pea fiber, noted that its soft part was even softer, although there had been a reduction in specific volume.

Despite the fact that the per capita bread consump- 
tion in Brazil is just half World Health Organization (WHO, 2003) recommendations of $60 \mathrm{~kg} / \mathrm{year}$, its ingestion is important, where a significant proportion of the global population consume amylaceous food due to its high glycemic response. Thus, bread is recommended in moderation for diabetic and obese individuals.

Studies have shown that besides these population groups, low glycemic index food should be recommended for those harboring heart disease as well as for healthy individuals, as it contributes to better sensitivity to insulin, which it is an important factor concerning the reduction of diabetes development risk (Caruso, Menezes, 2000; Letexier et al., 2003).

The goal of this study was to evaluate the effect of inulin addition on physical, nutritional, and sensory parameters of bread, bearing in mind the benefits of a low glycemic index food intake and knowledge on inulin's functional and technological properties.

\section{MATERIAL AND METHODS}

\section{Samples}

Samples comprised 3 groups of bread with different inulin proportions $(0 \%, 6 \%$ and $10 \%)$. Each group included three repetitions using flour (100\%) and inulin Raftiline HPX provided by the Bunge and the Beneo Companies, respectively. Pressed fresh biological yeast (4\%), hydrogenate vegetal fat $(6,0$ and $0 \%)$, whole milk $(60 \%$, $62 \%$, and $63 \%)$, crystal sugar $(1 \%)$ and salt $(2 \%)$ were purchased at local shops in Recife-PE. White bread, used as a standard for the glycemic index, was also purchased at local shops.

The bread was processed through a direct method (AACC, 2000) in an experimental bakery at the Bunge Company.

\section{Nutritional parameters}

The centesimal composition was determined in three replicates in standard and experimental samples 1 and 2, according to the Horowitz (2002) methods: moisture content (method 935.29), ash (method 930.22-32.3.08), ethereal extract (method 963.15-31.4.02), proteins (method 991.20-33.2.11), and dietary fiber (985.29-45.4.08). The total carbohydrates were determined by the difference among these constituents.

The determination of glycemic index (GI) in vitro was done using an enzymatic method, according to Salgado et al. (2006), from samples dried on a ventilated stove at $104{ }^{\circ} \mathrm{C}$ for 1 hour.
The hydrolysis curve area of glucoses was calculated by the graphic analysis program (Findgraph, 2002), based on the relationship between the reference food curve area (white bread) and the hydrolysis curve of the case food studied (Salgado et al., 2006).

\section{Physical parameters}

Physical analyses were done on three samples, including mass, specific volume, and density measurements. Sample masses were determined on semi-analytical digital scales, and the volume was determined by the displacement of mustard seeds, considering the principle of water displacement through the inflow-outflow technique; the specific volume was determined based on the volume/mass ratio of the atmosphere (EL-dash et al., 1994).

\section{Sensory analysis}

A selected and trained sensory panel, made up of six experienced panelists, evaluated the samples using quantitative descriptive analysis (QDA); the generation of terminology and the other steps were performed according to the ABNT NBR 12806 (1993) and Stone and Sidel (2004). A $9 \mathrm{~cm}$ line scale was used (running from "none" to "very intense") and panelists were trained for 6 sessions of 2 hours each. The repetition, discrimination and homogeneity of the judges' scores were checked by two-way ANOVA analysis. The development of terminology was based on a net grid method, whereby the products were offered to panelists, so that their differences and similarities could be listed (Dutcosky, 2007).

The bread formulation adopted in this experiment is described in the item Samples. Single samples $(25 \mathrm{~g})$ were introduced to panelists at room temperature $\left(21 \pm 2^{\circ} \mathrm{C}\right)$ in white pottery dishes covered by a watch glass, and codified by three random digits . During the evaluation, panelists were allowed to drink water.

The three sessions were carried out in the morning $(9 \mathrm{~h})$, at one week intervals. The sensory test was a quantitative descriptive analysis, incorporating a $9 \mathrm{~cm}$ line scale (Stone, Sidel, 2004). The evaluated attributes of the bread were volume, crest color, shape, symmetry, and general characteristics of crust. For a $1 \mathrm{~cm}$-thick sliced loaf, the aroma, color, porosity, crumb texture, flavor and unctuosity (property of spreading butter on bread) were evaluated. For the latter attribute, panelists were instructed to spread butter $(1 \mathrm{~g} /$ slice $)$ using a spatula.

The attributes were analyzed based on their respective factors of importance regarding the quality of bread, according to Dutcosky (2007): aroma (2), volume (3), 
color of the crust (2), shape and symmetry (2), general characteristics of crust (3), crumb color (1), crumb porosity (2), texture (2), flavor (2) and unctuosity (1). The scores of each product were calculated by the adding the attribute averages multiplied by the factors. The bread samples were then classified as good quality of bread ( $81-100$ points), regular $(61-80)$, bad - unacceptable quality $(31-60)$ and very bad $(\leq 30)$.

\section{Statistical analysis}

The data on sensory characteristics were analyzed by the Chi-square test. The parametric data were evaluated using Student's t-test, adopting a 5\% significance level in all cases (Statsoft, 1996).

\section{RESULTS AND DISCUSSION}

\section{Nutritional parameters}

The bread centesimal composition (Table I) evidences that, as expected, fat substitution caused a significant $85 \%$ (sample 1) and $80 \%$ (sample 2 ) reduction in ethereal extract, compared to the standard bread. These results enabled the bread to be classified as light or low-fat content (Brasil, 1998). In terms of caloric value, the replacement of fat by inulin led to an $11 \%$ and $17 \%$ reduction for experimental samples 1 and 2, respectively. Therefore, only the latter sample was significant.

TABLE I - Centesimal composition of bread with added inulin

\begin{tabular}{lccc}
\hline Analyses & $\begin{array}{c}\text { Standard with } \\
0 \% \text { inulin } \\
(\mathrm{g} / 100 \mathrm{~g})\end{array}$ & $\begin{array}{c}\text { With } \\
6 \% \text { inulin } \\
(1)(\mathrm{g} / 100 \mathrm{~g})\end{array}$ & $\begin{array}{c}\text { With } \\
(2)(\mathrm{g} / 100 \mathrm{~g})\end{array}$ \\
\hline Moisture content & $28.8 \pm 2.3^{\mathrm{a}}$ & $29.6 \pm 3.0^{\mathrm{a}}$ & $30.8 \pm 2.5^{\mathrm{a}}$ \\
Ash & $2.6 \pm 0.2^{\mathrm{a}}$ & $2.5 \pm 0.2^{\mathrm{a}}$ & $2.6 \pm 0.2^{\mathrm{a}}$ \\
Protein & $12.4 \pm 0.4^{\mathrm{a}}$ & $12.3 \pm 0.4^{\mathrm{a}}$ & $12.1 \pm 0.5^{\mathrm{a}}$ \\
Ethereal extract & $6.6 \pm 0.4^{\mathrm{a}}$ & $1.0 \pm 0.2^{\mathrm{b}}$ & $0.9 \pm 0.3^{\mathrm{b}}$ \\
Total carbohydrate & $49.6 \pm 1.7^{\mathrm{a}}$ & $54.7 \pm 2.1^{\mathrm{a}}$ & $53.6 \pm 2.0^{\mathrm{a}}$ \\
Dietary fiber & $5.0 \pm 0.9^{\mathrm{a}}$ & $5.2 \pm 0.8^{\mathrm{a}}$ & $8.0 \pm 0.4^{\mathrm{b}}$ \\
Total caloric value & $287.3 \pm 7.14^{\mathrm{a}}$ & $255.8 \pm 10.15$ & $238.5 \pm 11.4^{\mathrm{b}}$ \\
(Kcal/100g) & & $\mathrm{ab}$ & \\
\hline
\end{tabular}

*Values followed by different letters represent significant difference $\mathrm{p}<0.05$

In relation to dietary fiber content, the addition of $6 \%$ inulin did not cause a significant increase in this constituent. This fact can be attributed to both the sensitivity of the analytic method and the hydrolysis of soluble fibers by enzymes produced during fermentation, or perhaps to the partial destruction of inulin during cooking (AbdulHamid, Siew-Luan, 2000).

Figure 1 shows that $0 \%$ inulin standard white bread and its assessment achieved a lower value on hydrolysis of carbohydrate. This result for the standard bread is likely due to the presence of fat which can encapsulate starch grains hindering enzymatic hydrolysis and its subsequent absorption (Grossmann, Barber, 1997). Inulin's ability to absorb enough water can reduce grain intumescences and starch gelatinization thereby leading to lower hydrolysis (Brennan et al., 2004; Tudorica et al., 2002).

The GI of standard bread with $0 \%$ inulin was 82 , bread with $6 \%$ inulin was 85 and bread with $10 \%$ inulin, 82 . These results showed that the proportion of inulin used was not able to reduce in vitro GI to values less than or equal to 75 (Lajolo, Menezes, 2006).

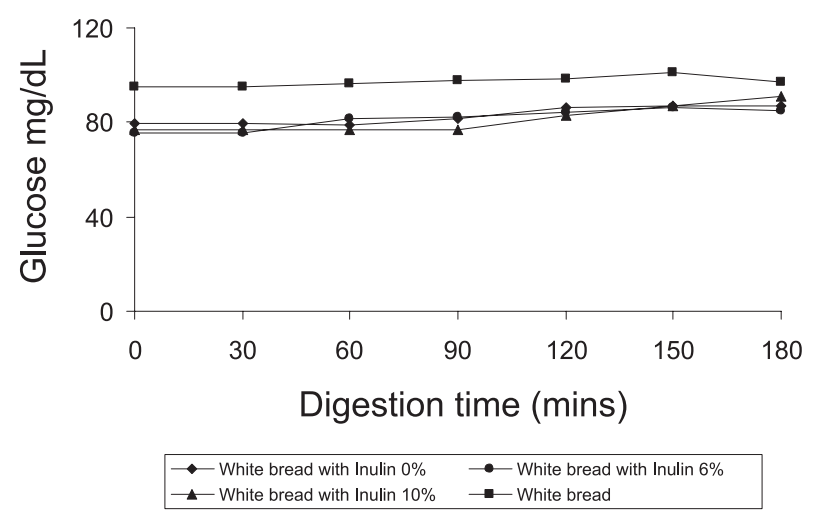

FIGURE 1 - Hydrolysis curve of bread carbohydrates.

However, in vivo studies have shown that soluble fibers are capable of reducing post-meal glycemic responses. A similar effect was registered by Brennan et al., (2004) for spaghetti with $10 \%$ added inulin. This data allow us infer that the effect of inulin on glycemia could be dependent on the process to which the food was submitted.

Comparing these research results with data reported in the literature (Table II), reveals that whole wheat bread is usually recommended for diabetic and overweight individuals, as it presents a higher GI than the bread studied in the samples, except for oat bread containing $50 \%$ flour, rye, flaxseed and soy.

\section{Physical parameters}

According to Table III, $10 \%$ inulin in bread produced a significant reduction in specific volume (41.66\%) in relation to the standard sample and (38\%) and compared 
TABLE II - Glycemic index of several types of bread

\begin{tabular}{lcc}
\hline Types of bread & GI* & GI** \\
\hline White Flour bread & 101 & 101 \\
$100 \%$ rye flour bread & 95 & 96 \\
$80 \%$ rye flour bread & 95 & 95 \\
Bread with oat seed & - & 93 \\
Oat bread with 50\% flour & - & 72 \\
Bread with rye seed & 71 & 58 \\
Dark Rye (black) bread & 92 & 109 \\
Light rye bread & - & 97 \\
White bread with high fiber & - & 96 \\
Linseed and soy bread & - & 71 \\
Whole wheat bread US & - & 104 \\
Whole wheat bread CAN & - & 102 \\
\hline
\end{tabular}

*Source: Caruso, \& Menezes, 2000.**Source: Foster-Powell, Holt, \& Brand-Miller, 2002.

to $6 \%$ inulin bread. Similar behavior of volume reduction was reported by Wang et al., (2002) when adding 3\% inulin to bread, and by O'Brien et al., (2003) in bread containing 5\% insulin. Studies carried out by Moinho Rio Negro (Ferreira et al., 2001) consider ideal specific volume to be 4 to $5 \mathrm{~cm}^{3} / \mathrm{g}$, which mirrors the results found for the samples containing $0 \%$ and $6 \%$ inulin.

The density and specific volume evidenced the relationship between the amount of solid and the fraction of air contained in baked dough. Products of higher density are associated to a high level of moisture (Esteller, Lannes, 2005). According to Grossman and Barber (1997) and Sánchez et al., (1998) bread volume is related to the processing method, quality and quantity of ingredients, particularly those that benefit the flour. Wang et al. (2002) highlighted that interactions between flour proteins and fiber added to the product, can prevent the expansion of bread during the fermentation period.

Characteristics of bread are illustrated in Figure 2. Experimental bread $\mathrm{C}$ showed larger alveolus and thinner walls, thus producing many holes. These characteristics had some effect on sensory evaluation, particularly on the descriptor "crumb porosity" which obtained the lowest scores according to Figure 2. Dough presenting a high liquid content tended to produce, after baking, products with larger alveolus (Esteller, Lannes 2005).
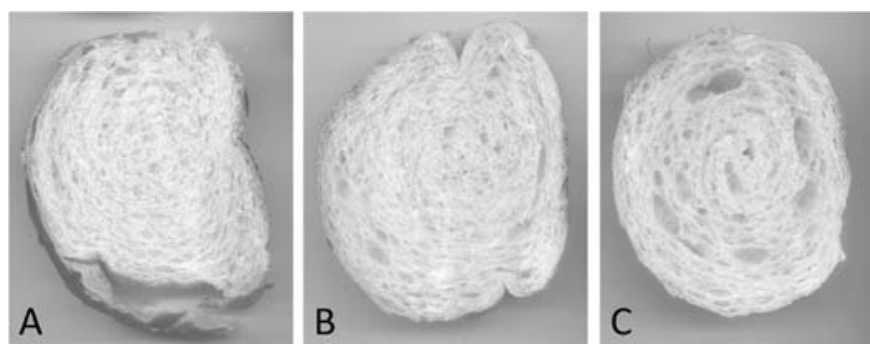

FIGURE 2 - Visual characteristics of bread with added inulin. $\mathrm{A}=$ standard bread with $0 \%$ inulin, $\mathrm{B}=$ bread with $6 \%$ inulin, $\mathrm{C}$ $=$ bread with $10 \%$ inulin

\section{Sensory parameters}

Analysis of results (Table IV and Figure 3) evidences that the most influential descriptors concerning bread evaluation were: volume, crust color, porosity and texture, on which $10 \%$ inulin in bread yielded the lowest scores, unlike the other formulations. Sommier et al. (2005) described several factors that interfere in the quality of bread including the quality of wheat, the dough treatment and the ingredients applied, as a result of color, flavor, volume and texture change.

The total score of experimental sample 2 was 73.3 , which according to Dutcosky, (2007), corresponds to regular quality bread. The other samples, whose scores exceeded 85, were classified as good quality bread. Wang et al. (2002) also obtained reasonably acceptable bread, despite a reduction in specific volume, when adding dietary staple fibers, including 3\% inulin. Korus et al., (2006) reported a similar result in a study of gluten-free bread supplemented with prebiotics, in which good quality products were obtained by introducing $5 \%$ inulin .

TABLE III - Physical analysis of bread samples with added inulin

\begin{tabular}{lccc}
\hline Physical parameters & Standard Bread 0\% inulin & Bread with 6\% inulin (1) & Bread with 10\% inulin (2) \\
\hline Weight $(\mathrm{g})$ & $57 \pm 1.6^{\mathrm{a}}$ & $58 \pm 1.5^{\mathrm{a}}$ & $59 \pm 0.8^{\mathrm{a}}$ \\
Volume $\left(\mathrm{cm}^{3}\right)$ & $269 \pm 3.1^{\mathrm{a}}$ & $259 \pm 19.6^{\mathrm{a}}$ & $168 \pm 21.9^{\mathrm{b}}$ \\
Specific volume $\left(\mathrm{cm}^{3} / \mathrm{g}\right)$ & $4.8 \pm 0.1^{\mathrm{a}}$ & $4.5 \pm 0.3^{\mathrm{a}}$ & $2.8 \pm 0.3^{\mathrm{b}}$ \\
Density $\left(\mathrm{g} / \mathrm{cm}^{3}\right)$ & $0.21 \pm 0.01^{\mathrm{a}}$ & $0.22 \pm 0.01^{\mathrm{a}}$ & $0.35 \pm 0.01^{\mathrm{a}}$ \\
\hline
\end{tabular}

*Values followed by different letters represent significant difference $\mathrm{p}<0.05$. 
TABLE IV - Weighted average of scores assigned to sensorial attributes of bread with added inulin

\begin{tabular}{|c|c|c|c|c|c|c|}
\hline \multirow{3}{*}{$\begin{array}{l}\text { Attributes } \\
\text { Volume }\end{array}$} & \multicolumn{6}{|c|}{ Scores (average and standard deviation) } \\
\hline & \multicolumn{2}{|c|}{ Standard with $0 \%$ inulin } & \multicolumn{2}{|c|}{ With $6 \%$ inulin (1) } & \multicolumn{2}{|c|}{ With $10 \%$ inulin (2) } \\
\hline & $13.8^{\mathrm{a}}$ & $\pm 1,5$ & $14,0^{\mathrm{a}}$ & $\pm 1,5$ & $10,3^{\mathrm{b}}$ & $\pm 2,1$ \\
\hline Crust color & $8.6^{\mathrm{a}}$ & \pm 1.1 & $7.8^{\mathrm{a}}$ & \pm 1.7 & $6.0^{\mathrm{b}}$ & \pm 1.2 \\
\hline Shape and symmetry & $9.0^{\mathrm{a}}$ & \pm 1.0 & $9.1^{\mathrm{a}}$ & \pm 1.0 & $9.1^{\mathrm{a}}$ & \pm 1.2 \\
\hline Crust characteristics & $12.7^{\mathrm{a}}$ & \pm 2.8 & $12.5^{\mathrm{a}}$ & \pm 2.6 & $11.0^{\mathrm{a}}$ & \pm 2.7 \\
\hline Crumb color & $4.9^{\mathrm{a}}$ & \pm 0.2 & $4.9^{\mathrm{a}}$ & \pm 0.3 & $4.8^{\mathrm{a}}$ & \pm 0.4 \\
\hline Crumb porosity & $8.1^{\mathrm{a}}$ & \pm 0.8 & $8.1^{\mathrm{a}}$ & \pm 0.5 & $5.4^{\mathrm{b}}$ & \pm 1.9 \\
\hline Texture & $9.1^{\mathrm{a}}$ & \pm 1.4 & $8.8^{\mathrm{a}}$ & \pm 1.7 & $6.6^{\mathrm{b}}$ & \pm 2.0 \\
\hline Aroma & $8.3^{\mathrm{a}}$ & \pm 1.2 & $8.2^{\mathrm{a}}$ & \pm 1.5 & $7.8^{\mathrm{a}}$ & \pm 1.2 \\
\hline Flavor & $8.4^{\mathrm{a}}$ & \pm 1.1 & $8.2^{\mathrm{a}}$ & \pm 1.2 & $7.8^{\mathrm{a}}$ & \pm 1.2 \\
\hline Unctuosity (greasiness) & $4.2^{\mathrm{a}}$ & \pm 0.9 & $4.6^{\mathrm{a}}$ & \pm 0.5 & $4.5^{\mathrm{a}}$ & \pm 0.5 \\
\hline Total Score & $87.2^{\mathrm{a}}$ & \pm 8.5 & $86.2^{\mathrm{a}}$ & \pm 7.1 & $73.3^{\mathrm{b}}$ & \pm 8.4 \\
\hline
\end{tabular}

*Values followed by different letters represent significant difference.

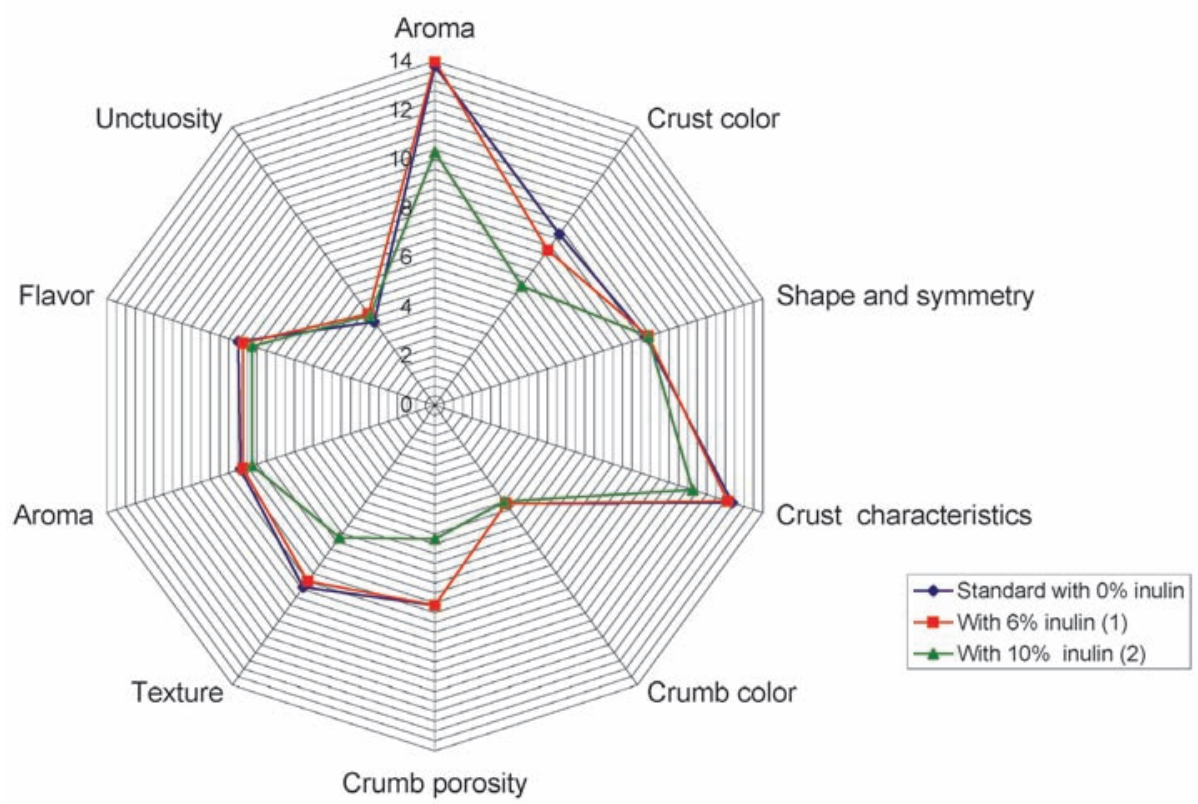

FIGURE 3 - Quantitative descriptive analysis of breads.

\section{CONCLUSION}

The $6 \%$ inulin experimental sample was sensorially rated as being of good quality. The percentage of inulin used altered the centesimal composition of the bread and consequently reduced its calories.

Although the products tested did not reach low GI values, they could be recommended to diabetics and overweight individuals for their high dietary fiber content.

\section{ACKNOWLEDGEMENTS}

The authors would like to thank the BUNGE Company for support in testing, and the BENEO Company for the inulin provided, as well as the Coordenação de Aperfeiçoamento de Pessoal de Nível Superior (CAPES) for the scholarship granted to the first author. 


\section{REFERENCES}

AMERICAN ASSOCIATION OF CEREAL CHEMISTS. Approved methods of the American Association of Cereal Chemists. 10.ed. Saint Paul: AACC, 2000. 1200p.

ABDUL-HAMID, A.; SIEW LUAN, Y. Functional properties of dietary fiber prepared from defatted rice bran. Food Chem., v.68, p.15-19, 2000.

\section{ASSOCIAÇÃO BRASILEIRA DE NORMAS TÉCNICAS.} NBR 12806: análise sensorial dos alimentos e bebidas. Rio de Janeiro: ABNT, 1993. 8p.

HOROWITZ, W. (Ed.) Official methods of analysis of the Association of Official Analytical Chemistry. 17.ed. Washington: AOAC, 2002. v.2.

BRASIL. Portaria n.27, de 13 de janeiro de 1998. Regulamento técnico referente à informação nutricional complementar. Available at: http://e-legis.anvisa.gov.br/leisref/public/. Accessed on: 25 jan. 2009.

BRENNAN, C. S.; KURI, V.; TUDORICA, C. M. Inulin enriched pasta: effects on textural properties and starch degration. Food Chem., v.86, p.189-193, 2004.

CAPITO, S. M. P.; FILISETTI, T. M. C. C. Inulina: um ingrediente alimentar promissor. Cad. Nutr., v.18, p.1-11, 1999.

CARUSO, L.; MENEZES, E. W. Índice glicêmico dos alimentos. Nutrire, v.19, n.20, p.49-64, 2000.

DUTCOSKY, S. D. Análise sensorial de alimentos. 2.ed. Curitiba: Champagnat, 2007. 239 p.

EL-DASH, A. A.; MAZZARI, M. R.; GERMANI, R. Tecnologia de farinhas mistas: uso de farinha mista de trigo e milho na produção de pães. EMBRAPA-CTAA, v.1, p.42-88, 1994.

ESTELlER, M. S.; LANNES, S. C. S. Parâmetros complementares para fixação de identidade e qualidade de produtos panificados. Ciênc. Tecnol. Aliment., v.25, n.4, p.802-806, 2005.

FERREIRA, S. M. R.; OLIVEIRA, P. V.; PRETO, D. Parâmetros de qualidade do pão francês. Bol. Cent. Pesqui. Process. Aliment., v.19, n.2, p.301-318, 2001.
FINDGRAPH for Windows. Vancouver: Uniphiz Lab, 2002.

FOSTER-POWELL, K.; HOLT, S. H. A.; BRAND-MILLER, J. C. International table of glycemic index and glycemic load values. Am. J. Clin. Nutr., v.76, n.1, p.5-56, 2002.

FRANCK, A. echnological functionality of inulin and oligofructose. Br. J. Nutr., v.87, n.2, p. S287-S291, 2002.

GROSSMAN, M. V. E.; BARBER, C. B. Envejecimento del pan: efecto combinado de $\alpha$ - amilasa bacteriana y emulsicante en la textura e en las características amilográficas de la miga. Arch. Latinoam. Nutr., v.47, n.3, p.229-233, 1997.

KORUS, J.; GRZELAK, K.; ACHREMOWICZ, K.; SABAT, $R$. Influence of prebiotic additions on the quality of gluten-free bread and on the content of inulin and frucyooligosaccharides. Food Sci. Technol. Int., v.12, n.6, p.489-495, 2006.

LAJOLO, F. M.; MENEZES, E. W. Carboidratos en alimentos regionales Iberoamericanos. São Paulo: EDUSP, 2006. $648 \mathrm{p}$.

LETEXIER, D.; DIASION, F. BEYLOT, M. Addition of inulin to a high carbohydrate diet reduces hepatic lipogenesis and plasma triacyglycerol concentration in humans. Am. J. Clin. Nutr., v.77, n.3, p.559-564, 2003.

O'BRIEN, C. M.; MUELLER, A.; SCANNELL, A. G. M.; ARENDT, E. K. Evaluation of the effects of fats replacers on the quality of wheat bread. J. Food Eng., v.56, n.2, p.256-267, 2003.

SAAD, S. M. I. Probióticos e prebióticos: o estado da arte. Rev. Bras. Cienc. Farm., v.42, n.1, p.1-16, 2006.

SALGADO, S. M.; LIVERA, A. V. S.; GUERRA, N. B.; SCHÜLLER, A. R. P.; ARAÚJO, A. L. L. Resposta fisiológica in vitro do amido do feijão macassar (Vigna unguiculata L. Walp). Braz. J. Food Technol., v.9, n.4, p.297-303, 2006.

SÁNCHEZ, H. D.; OSELlA, C. A.; TORRE, M. A. G. Mejoramiento de la calidad nutricional de pan tipo francés. Arch. Latinoam. Nutr., v.48, n.4, p.349-353, 1998.

SOMMIER, A.; CHIRON, H.; COLONNA, P.; VALLE, G. D.; ROUILLÉ, J. An instrumented pilot scale oven for study of French bread baking. J. Food Eng., v.69, n.1, p.97-106, 2005. 
STATSOFT INC. Statistica for windows. Tulsa: STATSOFT, 1996.

STONE, H.; SIDEL, J. L. Sensory evaluation practices. 3.ed. Redwood City: Academic Press, 2004. 337 p.

TUDORICA, C. M.; KURI, V.; BRENNAN, C. S. Nutritional physicochemical characteristics of dietary enriched pasta. J. Agric. Food Chem., v.50, n.2, p.347-356, 2002.
WANG, J.; ROSELL, C. M.; BARBER, C. B. Effect of the addition of different fibres on dough performance and bread quality. Food Chem., v.79, n.2, p.221-226, 2002.

WORLD HEALTH ORGANIZATION. Diet, nutrition and the prevention of chronic diseases. Geneve: WHO, 2003. 160 p. (Technical Report Series, 916).

Received for publication on $01^{\text {st }}$ December 2009 Accepted for publication 02 ${ }^{\text {nd }}$ August 2010 
